Revista de Derecho

de la Pontificia Universidad Católica de Valparaíso

LV (Valparaíso, Chile, 2do semestre de 2020)

[pp. 261-274]

\title{
Forced Heirship and Disposable Portion Under the Tegulations of the New Romanian Civil CODE
}

[Herencia forzada y porción disponible según las reglas del nuevo Código Civil Rumano]

\author{
ILIE URS \\ Faculty of Law of Cluj-Napoca \\ Dimitrie Cantemir Christian University of Bucharest
}

\begin{abstract}
RESUMEN
La herencia forzosa es la parte de la herencia que corresponde por ley a los herederos forzosos, incluso contra la voluntad del causante manifestada a través de liberalidades o mediante repudio. En oposición a la herencia/reserva, la parte de la herencia que el causante puede disponer libremente de su patrimonio se conoce como porción disponible. En caso de existir herederos forzosos y que el causante haya hecho en vida donaciones o legados, la herencia que queda se divide en dos: herencia forzosa y porción disponible. La herencia forzosa se justifica por el hecho de que su sentido es preservar para la familia una parte del patrimonio dejado por el causante, siendo asignada a parientes consanguíneos del causante y a la viuda.
\end{abstract}

\section{Palabras Clave}

Causante - cuadro de herederos desheredación - herederos - herencia - liberalidades - sucesión forzosa.

\section{Abstract}

Forced heirship is the part of the inheritance assets to which forced heirs are entitled under the law, even against the will of the deceased, manifested through liberalities or by disowning. In opposition to heirship/reservation, the part of the inheritance within which the one leaving it can freely dispose of their goods is known as disposable portion. In case there are forced heirs and the deceased person has made during his lifetime donations or bequests, the chart of heirs left behind is divided into two parts: forced heirship and disposable portion. Forced heirship is justified by the fact that it has been and it is meant to preserve a part of the assets left by the deceased person in the family, being conferred to blood relatives close to the deceased and to the surviving spouse.

KEY WORDS

Chart of heirs - deceased - disinheritance - forced heirship - heirs - inheritance - liberalities.

RECIBIDO el 22 de enero de 2020 y ACEPTADO el 30 de noviembre de 2021 


\section{FOREWORD}

Subsequent to Romania's accession to the European Union and as a result of the changes of civil law in other countries, beginning with 2004, the project of drafting a new civil code was initiated, meant to meet modern social and legal requirements and to fit the current institutional and social climate of Romania ${ }^{1}$. After a sustained work of several years, the normative deed was adopted by Law n. 287 of July 17, 2009² and implemented on October the 1st, 2011.

The new Civil Code brings elements of novelty in the field of the inheritance law, adapting civil norms and regulations to nowadays realities and to the reforming tendencies manifested in other law systems. For example, in relation to the topic of the given study, it regulated a unitary and simple system used to calculate the forced heirship and the disposable portion.

In compliance with art. 953 of the Romanian Civil Code ${ }^{3}$, inheritance is the transfer of the estate of a deceased natural person to one or more persons alive. The word "succession" is also used, being given the same meaning in the matter of the inheritance law. The terms "inheritance" or "succession" are also used to designate the estate of the deceased natural person which is passed on to their heirs ${ }^{4}$.

Some of the heirs of the deceased person ${ }^{5}$ namely their descendants (children, grandchildren, great-grandchildren, etc.), parents and surviving spouses are entitled, under the law, to a portion of the inheritance, even against the liberal will of the late person. They are defended by law, as far as this portion of the inheritance is concerned, against donations ${ }^{6}$ and

${ }^{1}$ The former Romanian Civil Code dated 1864, published in the Official Gazette No. 271 of December, the 4th 1864, as subsequently amended and supplemented, did not reflect anymore the social and economic realities of Romania. It was therefore necessary to adopt a modern instrument to regulate the fundamental aspects of individual and social existence, able to respond to the imperatives of a dynamic and constantly changing present. However, many of the provisions of the former Romanian Civil Code can be found in the new normative deed.

${ }^{2}$ Published in the Official Gazette of Romania, Part I, no. 511 dated July, the 24th 2009. For the creation of the new Civil Code more models were used such as the civil codes of France, Italy, Spain, Swiss, Germany, Brazil and especially the civil code of the province Quebec.

${ }^{3}$ The references mentioned in the given study further on refer to the new Romanian civil Code, implemented on the $1^{\text {st }}$ October 2011. In case we refer to the former Civil Code dated 1864, we will mention the references as belonging to it.

${ }^{4}$ See Urs, Ilie, Drept civil. Succesiuni. Curs universitar ["Civil Law. Successions. An Academic course”] (București, Universul Juridic, 2015) p. 15.

${ }^{5}$ The dead person is referred to as late person or deceased person or de cujus.

${ }^{6}$ Based on art. 985 of the new Romanian Civil Code, donation is the contract 
legacies ${ }^{7}$ made by the deceased/late person during his lifetime. These heirs are known as forced heirs, and the portion of the inheritance which the law passes on to them is known as forced heirship. In opposition to heirship/ reservation, the part of the inheritance within which the one leaving it can freely dispose of their goods is known as disposable portion. Therefore, in case there are forced heirs and the deceased person made during his lifetime donations or bequests, the chart of heirs (the inheritance) ${ }^{9}$ left behind is divided into two shares: forced heirship and disposable portion.

\section{THE NOTIONS OF "FORCED HeIRSHIP" AND "DISPOSABLE PORTION"}

According to art. 1086 of the Romanian Civil Code, inspired by art. 912 paragr. 1 of the French Civil Code, forced heirship is the portion of the inheritance goods to which the forced heirs are entitled by law, even against the will of the late person, manifested by liberalities (donations and bequests) or disinheritances (terms covered by wills, by which the testator removes some or all legal heirs from the inheritance).

According to the provisions of art. 555 and 556 of the Romanian Civil Code, the owner may freely dispose of their assets, such freedom not being though absolute, but limited ${ }^{10}$ by the provisions of the law, in certain cases. One of these cases refers to forced heirship. Therefore, if the late person has forced heirs, the liberalities and disinheritances which he initiated during his lifetime must observe certain limitations, under the law, so that they should not affect (diminish) the forced heirship. The law limits only the right to dispose through liberalities, and not through legal onerous or gratuitous deeds. And this because only the liberalities and disinheritances can affect the heirs (in the sense that they can diminish

by which, with the intention of gratifying a party called donor/granter irrevocably disposes of a good in favor of the other party, called grantee.

${ }^{7}$ By bequest we should understand, based on art. 986 of the new Romanian Civil Code, the devise by which the testament originator stipulates that, on his death, one or more legatees (devisees) will inherit the entire patrimony, a fraction of it or certain well individualized goods/assets.

${ }^{8}$ See Eliescu, Mihail, Mos tenirea si devolut iunea ei in dreptul Republicii Socialiste Români ["Inheritance and its devolution in the law of the Socialist Republic of Romania”] (București, Editura Academiei Republicii Socialiste România, 1966) p. 320 .

${ }^{9}$ With the meaning of inheritance, namely the assets, rights and patrimonial obligations that the deceased natural person leaves at the end of his life and which form the object of the inheritance right of his heirs.

${ }^{10}$ Based on art. 556 parágr. 2 of the Romanian Civil Code, the law can limit the exercise of the ownership attributes. 
the chart of heirs), and not legal onerous deeds, as the latter always bring something in exchange for the estranged good or goods ${ }^{11}$.

By regulating the forced heirship proceedings the legislator protects forced heirs against excessive donations and testamentary legacies/bequests made by the deceased in favour of third parties, making sure that they receive at least a part of the inheritance which belongs to them by law. Moreover, forced heirship defends forced heirs not only against the excessive liberalities made in favour of foreign persons, but also against the liberalities made in favour of some legal forced heirs. For example, in case the deceased has more children, he can only gratify one of them by respecting the heirship of the others ${ }^{12}$. It therefore results that no liberalities can be made in favour of the surviving relatives or spouse beyond the limits in which they can be made to tierces, namely within the limits of the available disposable portion ${ }^{13}$.

The available disposable portion is, according to art. 1089 of the Romanian Civil Code (inspired by art. 912 paragr. 2 of the French Civil Code) that a part of the assets of the inheritance that is not reserved by law and which the deceased could unrestrictedly dispose of through liberalities

In case the originator of the inheritance has ordered liberalities over the limits of the available disposable portion, after his death, by request of the forced heirs, such legal deeds are subject to reduction, being abolished, in whole or in part, to the extent of the entire forced heirship.

\section{THE EMERGENCE OF THE FORCED HEIRSHIP. SHORT HISTORY}

In the old Roman law, in Rome, during the kingdom and in the early days of the republic, the property law was absolute and perpetual. The family parent (pater familias), who had children, wife and slaves under his authority, was free to dispose of the family assets by will, and such liberty knew no limits. It will be legal as it was ordered by the will, as the Law of the Twelve Tablets tells us ${ }^{14}$.

Towards the end of the Republic, subsequent to the great conquests and based on the wealth acquired in this way, the Roman family begins to fall apart and the rights of the head of the family were restricted. Full

${ }^{11}$ See CHIRICĂ, Dan, Tratat de drept civil. Succesiunile si liberalitatile ["A Civil law Treaty. Successions and Liberalities”] (Bucharest, C. H. Beck, 2014) p. 391-392.

${ }^{12}$ See DeAK, Francisc - Popescu, Romeo, Tratat de drept succesoral, II. Mosterinea testamentara ["A Treaty of the Succession Law, II. Testamentary Inheritance"] (3a ed., București, Universul Juridic, 2014) p. 249.

${ }^{13}$ See CHIRICĂ, Tratat, cit. (n. 11) p. 392.

${ }^{14}$ See Eliescu, cit. (n. 8) p. 320. 
testamentary freedom is no longer allowed, as in many situations the pater familias made scandalous disinheritances of close relatives. There were philosophers, such as Plato, who advocated the abolition of testamentary freedom, thus attempting to ensure the preservation of family property ${ }^{15}$.

As an attempt to remedy this state of facts and aiming for the ancestral assets to remain in the important families, who could thus preserve their political role in the Romanian state, the judicial practice imposed the rule according to which a will leaving nothing to close relatives was incompatible with the most elementary family moral duties (officium pietatis), and the testator was crazy. This rule, practiced by the court of centumviri, which would judge the inheritance processes, allowed close relatives, harmed by such testamentary dispositions, to attack the wills by an action called querela inofficiosi testamenti (the complaint against the indecent will). The close relatives who could register this action were the descendants, the ascendants, brothers and sisters of the pater familias. In case the claimant would win the trial, the will deemed to be the work of a lunatic, was cancelled, the legal inheritance being thus initiated ${ }^{16}$.

The requirement for the aforementioned persons to initiate the action was that they had not received the part of the inheritance which they were entitled to (the heirship), counted to a quarter of what they would have received as legal heir (quarta legitima).

The post-classical era witnesses many reforms in connection with this action (querela), and the Emperor Justinian establishes the heirship amount depending on the number of the testator's children. At the same time, the scope of the querela action is limited in the sense that whenever the forced heir had received something of the inheritance, regardless of the quantity, he was entitled to a single action to complete the legal amount of the heirship. Only the forced heir who had received nothing from the inheritance could try querela inofficiosi testamenti $i^{17}$.

But the system described above regarding the querela action protected forced heirs only against testamentary bequests, not against donations. As a result, the head of the family could dispossess his wealth through donations during his lifetime thus harming this own forced heirs, to whom nothing would remain. To remedy such inconvenient, imperial constitutions had extended the querela rules over the donations made by the late person/ defunct against his forced heirs (querela inofficiosae donationis) ${ }^{18}$.

${ }^{15}$ See Eliescu, cit. (n. 8) p. 321.

${ }^{16}$ See Hanga, Vladimir, Drept privat roman. ["Private Roman Law"] (București, Didactică şi Pedagocică, 1977) pp. 331-332.

${ }^{17}$ See Hanga, cit. (n. 16) p. 332.

${ }^{18}$ See Hanga, cit. (n. 16) p. 333. 
The feudal order in Western Europe was hostile to will and testamentary freedom. At that time, economic and political power was related to land ownership, this was the reason for which preserving the inherited property in the family of origin was an imperative necessity. As a result, the right to test was restricted, by establishing a $4 / 5$ forced heirship/reserve, as these goods were production means and had to pass over to the relatives of the line where they came from ${ }^{19}$. For example, some customs (habits), such as those of Paris, would practice this 4/5 heirship of the inheritance, called the customary forced heirship, which was granted to all blood heirs who accepted the inheritance ${ }^{20}$.

Further on, the French Civil Code (the Napoleon Code) merged the Romanian legitimate heirship with the customary forced heirship, consecrating the principle that the forced heirship is part of the inheritance ${ }^{21}$. The Romanian Civil Code of 1864 and then the new Civil Code in force since 1 October 2011, undertaking the force heirship principle from the Code of Napoleon, has also undertaken the principles which laid its foundation ${ }^{22}$.

\section{GROUNDS OF FORCED HEIRSHIP}

Forced heirship has been and still is one of the most controverted institutions of the inheritance law. At a European level the following two large systems were created: i) a system which does not recognize the right to forced heirship, consecrating the principle of absolute testamentary freedom ${ }^{23}$; e.g., Anglo-Saxon law systems; ii) a system which regulates the forced heirship law, as a limitation of the right to dispose of the inheritance assets; for example the continental European law systems that enshrine the principle of the forced heirship protection, with only some differences regarding the circle of forced heirs and the amount of the heirship ${ }^{24}$.

In both systems, a large number of arguments were formulated, for and against forced heirship.

It was claimed against forced heirship that this is one of the main causes of family disintegration as it destroys the authority of the estate owner, denying him the possibility of distributing the assets according to the skills of each family member ${ }^{25}$. It was also claimed that it encourages

\footnotetext{
${ }^{19}$ See Eliescu, cit. (n. 8) p. 321.

${ }^{20}$ See CHIRICĂ, Tratat, cit. (n. 11) p. 394.

${ }^{21}$ See Eliescu, cit. (n. 8) p. 322.

${ }^{22}$ See ChIrICă, Tratat, cit. (n. 11) p. 394.

${ }^{23}$ See Deak - Popescu, cit. (n. 12) p. 249.

${ }^{24}$ Ibidem, p. 250.

${ }^{25}$ Ibidem, p. 251.
} 
inactivity (parasitism), as the heirs who receive a significant part of the inheritance under the title of forced heirship are no longer motivated to work and generate wealth ${ }^{26}$.

The following arguments were brought in favour of forced heirship:

a) First of all, forced heirship is justified by the existence of a natural duty of piety (officium pietatis) between parents and children, nephews and also between spouses. If the inheritance originator is granted the right to dispose of his property indefinitely, there could be situations when some parents would alienate their entire wealth for free, leaving nothing to their children, which is unacceptable. In the same way children could freely dispose of their property, without being interested in the material situation of their parents. These issues also arise between spouses. Therefore, the continental European legislator intended parents and children to be forced to leave some of their property untouched before making liberals to foreigners, thus fulfilling a duty imposed on them by nature. ${ }^{27}$

b) In a second place, the principle of protecting forced heirship also interests society as a whole should there be no forced heirship, some people who lived to a high standard of living could come at once to a precarious material situation and thus commit antisocial acts in order to keep some standard of living which they have become accustomed to. Thus because every human being has a natural tendency to maintain their normal living conditions and to try to improve them. Or, they do not always use legal means to get a better material situation which they have become accustomed with. Therefore forced heirship has been conceived as a legal instrument that ensures relative equality between heirs, the family cohesion and strength, suppressing anti-family liberalities - a source of hatred and discord between members of the same family ${ }^{28}$.

The new Romanian Civil Code system and the French Civil Code system consider that the social and family duty of passing on to close relatives a part of the inheritance prevails over the freedom of freely disposing of somebody's own assets and inheritance ${ }^{29}$.

Forced heirship is justified by the fact that it has been and is meant to preserve a part of the assets left by the late person in the family, being

\footnotetext{
${ }^{26}$ See UrS, cit. (n. 4) p. 164.

${ }^{27}$ See Deak - Popescu, cit. (n. 12) p. 250.

${ }^{28}$ See for details Deak - Popescu, cit. (n. 12) p. 251.

${ }^{29}$ See CHIRICĂ, Dan, Drept civil. Succesiuni şi testamente ["Civil Law. Successions and Wills"] (Bucharest, Rosetti, 2003) p. 301.
} 
conferred to the late person's close blood relatives and to the surviving spouse $^{30}$.

The new Romanian Civil Code focused, on one hand, on maintaining forced heirship, due to its role and importance in society. But, regardless of who forced heirs are and regardless of their number, forced heirship cannot exceed half the inheritance. On the other hand, a reasonable available disposable portion (the other half of the inheritance) was intended to be regulated, which the testator can use as he wishes, in support of one or other of the forced heirs. For example, for the benefit of one of the children who has reduced physical or intellectual possibilities, who has a larger family, health problems etc. ${ }^{31}$, or even in support of foreign helpless tierces.

\section{LEGAL FEATURES OF FORCED HEIRSHIP}

Forced heirship has the following particularities.

\section{Forced heirship is a part of the inheritance ("pars hereditatis") 32}

As it results of the provisions of art. 1086 of the civ. Code, forced heirship is the "part of the inheritance assets" which is due under the law to forced heirs even against the will of the late person.

Forced heirship, as part of the inheritance, is determined (calculated) on the inheritance opening date ${ }^{33}$. It will take into account not only the estate of the late person at the date of the inheritance opening, but also the donations made by the deceased during their lifetime, which are added to the net assets of the estate for the forced heirship calculation.

Forced heirship goes to forced heirs in their quality of legal heirs, according to the rules of the legal return of the inheritance ${ }^{34}$.Consequently,

${ }^{30}$ See CHIRICă, Tratat, cit. (n. 11) p. 398.

${ }^{31}$ Ibidem, p. 252.

${ }^{32}$ See DeaK - Popescu, cit. (n. 12) pp. 252-253; Chirică, Tratat, cit. (n. 11) p. 395; Macover, Codrin - Dobrilă, Mirela Carmen, Noul Cod Civil. Commetariu per articole 1-2644 ["The New Civil Code. Comments on articles. Art. 1-2664"] (București, C. H. Beck, 2012) p. 1118; URS, cit. (n. 4) p. 165-166; BACACI, Alexandru - ComăNiȚă, Gheorge, Drept civil. Succesionile ["Civil Law. Successions"] (București, Universul Juridic, 2013) p. 155; FloresCu, Dimitru C. Drept succesoral. In noul Cod civil ["Succession Law with the new Civil Code"] ( $3^{\mathrm{a}}$ ed. București, Universul Juridic, 2012), p. 129; ElIESCU, cit. (n. 8) p. 324.

${ }^{33}$ The inheritance opening date coincides with the death of the natural person originator of the inheritance.

${ }^{34}$ See DeAK, Francisc, Tratat de drept succesoral ["Successional Law Treaty"] (3a ed., București, Universul Juridic, 2002) p. 303. 
it can be claimed only by forced heirs (surviving spouse, descendants and privileged descendants of the deceased), who effectively participate to the inheritance, meaning those who meet the requirements under the law to inherit and who have accepted the inheritance. Those who give up the inheritance are not entitled to forced heirship. Moreover, in the presence of the descendants, the parents of the deceased are not entitled to forced heirship because, as part of the second class of legal heirs, they have no legal quality to the inheritance. Furthermore, in the presence of children, grandchildren do not have the right to claim forced heirship as they are relatives of the second degree with the deceased, removed from inheritance by the children, who are relatives of the first degree.

As it is considered part of the inheritance, the collection of forced heirship implies the obligation of the forced heirs to pay the inheritance debts and fees.

Forced heirs cannot make deeds of acceptance or of renunciation of the heirship before the opening inheritance date, as such deeds on a closed inheritance are struck by absolute nullity (art. 956 of the Romanian Civil Code).

\section{Forced heirship is imperative (of public order)}

The length of the forced heirship and the forced heirs are imperatively established by law ${ }^{35}$, and cannot be modified by the will of the late person, not even by agreement of the future forced heirs. Consequently, the will provisions by which the inheritance owner changes the circle of forced heirs or the amount of the forced heirship or encumbers duties on it are struck by absolute nullity ${ }^{36}$. To this effect, the supreme court of Romania has decided that the inheritance owner is prohibited any provisions, tasks, conditions or clauses that would prejudice the rights of the forced heirs ${ }^{37}$.

It should be noted however that the law establishes only the right to reserve, but not the obligation to exercise this right. Subsequent to the inheritance opening the forced heir may waive the right conferred by law.

We also specify that the right to forced heirshipis a personal right, born by law directly in the person of forced heirs on the inheritance opening date and not acquired from the deceased by inheritance ${ }^{38}$.

${ }^{35}$ See Macovei - Dobrilă, cit. (n. 32) p. 1118; Chirică, Tratat, cit. (n. 11) pp. 395-396; DeAK - Popescu, cit. (n. 12) p. 253.

${ }^{36}$ DeAK - Popescu, cit. (n. 12) p. 254.

${ }^{37}$ See the Supreme Court of Justice, civil judgm., Dec.no. 1314/1994, in the magazine Law no 7/1995, p. 87.

${ }^{38}$ DeaK - Popescu, cit. (n. 12) p. 254. 


\section{Heirship is attributed in kind}

Forced heirs are entitled to in kindheriship ${ }^{39}$, and not to its equivalent in money. In other words, they have the right to receive inheritance assets in kind, as they are owners of the heirship/inheritance. They are not creditors of the inheritance for the value of the forced heirship, meaning that they cannot be obliged to satisfy themselves with the value of their part of the inheritance, but they have the right to demand the goods in kind. ${ }^{40}$.

Naturally, the forced heir may accept the allocation or the completion of the forced heirship in the form of the equivalent in cash, as they have the right, but not the obligation, to claim the inheritance in kind. Moreover, if the value of the donated or left bound property falls within the limits of the available contribution, the beneficiary of the liberality will be able to keep it, and the inheritance will be allocated in kind from other assets existing in the inheritance, including money.

Only exceptionally, in the cases expressly provided by law, the inheritance may be allocated in the form of its equivalent in cash. For example, if the donor alienated the donated property before opening the inheritance and there are no other assets in the estate.

\section{Forced heirship is intangible, meaning that it cannot be diminished by} donations or by legacies 41

In the presence of forced heirs, the late person's liberalities, which could affect the forced heirship, are subject to reduction ${ }^{42}$ to the limit of the available disposable portion.

It does not mean though that the assets of the patrimony of a natural person alive are unavailable and, even less, inalienable and inseparable. During their lifetime, any person is free to dispose of their property, even

${ }^{39}$ Deak - Popescu, cit. (n. 12) p. 255; Chirică, Tratat, cit. (n. 11) p. 399; FloresCU, cit. (n. 32) p. 129; BACACI - COMĂNIȚĂ, cit. (n. 32) p. 155.

${ }^{40}$ See Mureşan, Mircea- Urs, Ilie, Drept civil. Succesiuni ["Civil Law. Succesions"] (Cluj-Napoca, Cordial Lex, 2006) p. 89. The legal practice has decided that the late person cannot violate the right to forced heirship in kind, ordering the sale of the building by auction and assigning or completing the forced heirship/ reserve from the price obtained (in this regard, see the Supreme Court of Justice), civ. decision., dec.no.1314/1994, quoted above).

${ }^{41}$ See Eliescu, cit. (n. 8) p. 325; DeAK, cit. (n. 34) p. 307; Macovei - Dobrilă, cit. (n. 32) p. 1118;

${ }^{42}$ Reduction is the civil sanction which intervenes if the liberalities made by the deceased exceed the available disposable portion, with prejudice to forced heirship. By the effect of this sanction, the liberalities that exceed the available disposable portion are reduced (totally or partially abolished) within the limit required to complete forced heirship. See Urs, cit. (n. 4) p. 187-188. 
for free, as the future and possible forced heirship does not mean inalienability, it only supposes that it cannot be diminished by donations or legacies or disinheritance ${ }^{43}$. For example, a person alive can make donations and can dispose of their entire fortune by testamentary legacies in favour of tierces. However, beginning with the inheritance opening moment, forced heirs have the right to request the reduction of excessive liberalities up to the limit of the available disposable portion.

Forced heirs cannot be disinherited by this forced heirship, as it is a part of the inheritance which the law defers imperatively to forced heirs without taking into account the free will of the deceased person ${ }^{44}$.

\section{FORCED HEIRS AND THE EXTENT OF FORCED HEIRSHIP}

According to art. 1087 of the Romanian new Civil Code, with the class of forced heirs fall the surviving spouse, the privileged descendants and ascendants of the late person ${ }^{45}$.

The descendants of the deceased are the children and their descendants in straight line to infinity, whether they are from marriage, outside marriage (with legally established filiation), from medically-assisted human reproduction with a third party donor or by adoption. Therefore, not only children but also grandchildren, great-grandchildren, great-grandchildren, etc., to infinity benefit of this forced heirship ${ }^{46}$. Grandchildren will though only benefit in the absence of children, only in the absence of children and grandchildren, etc.

Privileged ascendants are the parents of the deceased, i.e. the father and mother of the deceased, either from marriage, outside marriage, by adoption, as well as those who have resorted to medically-assisted human reproduction with a third party donor. Privileged ascendants will only benefit forced heirship in the absence of descendants.

As for the forced heirship extent, art. 1088 of the Romanian new Civil code provides that "forced heirship of each forced heir is half of the inheritance

\footnotetext{
${ }^{43}$ See Deak, cit. (n. 34) p. 307; Deak - Popescu, cit. (n. 12) p. 258.

${ }^{44}$ See Eliescu, cit. (n. 8) p. 326.

${ }^{45}$ The surviving spouse, the privileged descendants and ascendants are forced heirs in most of the Occidental European states (for example in Italy, Austria, Switzerland. etc).

${ }^{46}$ See UrS, cit. (n. 4) p. 180; DeAK - Popescu, cit. (n. 12) p. 260.
} 
share which, in the absence of liberalities or disinheritances, would have been assigned as a legal heir" ${ }^{\prime 4}$.

It results that in order to determine the forced heirship of each heir the inheritance quota of each forced heir must be determined as if they had collected the inheritance as legal heirs, whereas the heirship is half of this inheritance quota ${ }^{48}$. For example, if the late person has only one child as a forced heir, and by his will he instructed $\mathrm{X}$ as a universal legatee, leaving him the entire inheritance the legal inheritance share which the child would have received, in the absence of the will, would have been $1 / 1$ of the inheritance and his forced heirship is of $1 / 2$ of the inheritance, in the presence of the will.

\section{ESTABLISH FORCED HEIR AND THE AVAILABLE DISPOSABLE PORTION}

The forced heir and the available disposable portion are determined reported to the value of the chart of heirs on the inheritance opening date ${ }^{49}$. Based on art. 1091 paragr. 1 of the Romanian Civil Code, the value of the chart of heirs, according to which the forced heirship and the disposable portion is determined as follows: $i$ ) determine the gross inheritance asset, by summing up the value of the assets of the inheritance patrimony on the inheritance opening date (immovable, movable property, those subject to testamentary bonds and the value of the debt rights); ii) determine the net assets of the inheritance, by subtracting the inheritance passive from the gross assets; the inheritance passive consists of all the debts of the deceased existing on the inheritance opening date; iii) fictive reunion ${ }^{50}$, only for the calculus, at the net asset, of the value of the donations made by the inheritance originator; the value of the goods donated on the inheritance opening date is taken into account, considering their status at the time

${ }^{47}$ See also the High Court of Cassation and Justice of Romania, Judgment no. 4 dated 14 January 2019, published in the Official Gazette of Romaniano.132 dated 19 February 2019.

${ }^{48}$ See Deak - Popescu, cit. (n. 12) p. 258; Macovei - Dobrilă, cit. (n. 32) p. 1118.

${ }^{49}$ The chart of heirs should not be mistaken for the assets effectively identified in the late person's patrimony on the inheritance opening date. The notion of chart of heirs also includes beside these assets, the assets which the late person has donated during their lifetime, properties the value of which adds to the inheritance net asset (see URS, cit. (n. 4) pp. 184-185).

${ }^{50}$ This reunion (adding) is not effective, but purely fictive, only for calculation, to see if the liberalities made by the late person/ defunct range within the disposable portion limits. See DeAK - Popescu, cit. (n. 12) p. 296. 
of the donation, from which the value of the encumbrance sunder the donation contracts is deducted.

After the value calculation is made, in the order of the operations indicated above, forced heirship and the disposable portion is calculated and expressed by fractions from the unit which represents the chart of heirs ${ }^{51}$.

\section{CONCLUSIONS}

We consider that the regulation and recognition of the forced heirship by the new Romanian Civil Code is therefore justified. In case the testator is granted the right to dispose of his property indefinitely, there would be situations in which some parents would forfeit their entire wealth for free, leaving nothing to their children, which is unacceptable. We also believe that the social and family debt of passing on to close relatives a part of the inheritance assets prevails over the freedom of disposing freely of our own goods and assets. Forced heirship is justified as it is meant to preserve a part of the assets left by the deceased in the family, being granted only to blood relatives close to the deceased and to the surviving spouses. Given the facts, the advantages of recognizing forced heirship exceed the shortcomings of this institution.

\section{BiBLIOGRAPHY}

BACACI, Alexandru - ComăNițĂ, Gheorge, Drept civil. Succesionile ["Civil Law. Successions”] (București, Universul Juridic, 2013).

Chirică, Dan, Drept civil. Succesiuni și testamente ["Civil Law. Successions and Wills"] (București, Rosetti, 2003).

ChIRICĂ, Dan, Tratat de drept civil. Succesiunile si liberalitatile ["A Civil law Treaty. Successions and Liberalities"] (București, C. H. Beck, 2014).

DEAK, Francisc, Tratat de drept succesoral ["Successional Law Treaty"] (3a ed., București, Universul Juridic, 2002).

DeAK, Francisc - Popescu, Romeo, Tratat de drept succesoral, II. Mosterinea testamentara ["A Treaty of the Succession Law, II. Testamentary Inheritance"] (3a ed., București, Universul Juridic, 2014).

Eliescu, Mihail, Mos tenirea si devolut iunea ei in dreptul Republicii Socialiste Români ["Inheritance and its devolution in the law of the Socialist Republic of Romania”] (București, Editura Academiei Republicii Socialiste România, 1966).

Florescu, Dimitru C. Drept succesoral. In noul Cod civil ["Succession Law with the new Civil Code”] (3a ed. București, Universul Juridic, 2012).

Hanga, Vladimir, Drept privat roman. ["Private Roman Law"] (București, Didactică și Pedagocică, 1977).

\footnotetext{
${ }^{51}$ See ChIRICĂ, Drept civil, cit. (n. 29) p. 300.
} 
Macovei, Codrin - Dobrilă, Mirela Carmen, Noul Cod Civil. Commetariu per articole 1-2644 ["The New Civil Code. Comments on articles. Art. 1-2664"] (București, C. H. Beck, 2012).

Mureşan, Mircea- Urs, Ilie, Drept civil. Succesiuni ["Civil Law. Succesions"] (Cluj-Napoca, Cordial Lex, 2006).

Urs, Ilie, Drept civil. Succesiuni. Curs universitar ["Civil Law. Successions. An Academic course”] (București, Universul Juridic, 2015).

\section{JURISPRUDENCIA}

High Court of Cassation and Justice of Romania, Judgment n. ${ }^{\circ} 4,14$ January 2019, published in the Official Gazette of Romaniano, 132 dated 19 February 2019.

Supreme Court of Justice, civil judgm., December, n. ${ }^{\circ} 1314 / 1994$, in the magazine Law n. ${ }^{\circ}$ 7/1995, p. 87. 